\title{
Implementasi Algoritma Apriori Untuk Menentukan Pola Data Penyakit Pada Anak Usia Dini (Studi Kasus: RS. Estomihi)
}

\author{
Citra Verawati Purba, Efori Buulolo \\ Program Studi Teknik Informatika, STMIK Budi Darma, Medan, Indonesia \\ Email: citraverawati31@gmail.com \\ Submitted 15-04-2020; Accepted 23-04-2020; Published 26-04-2020
}

\begin{abstract}
Abstrak
Rumah Sakit merupakan tempat untuk menngani pasien dengan jenis penyakit yang berbeda-beda, dan rumah sakit juga merupakan salah satu pelayanan kesehatan yang bersifat pengobatan, penyembuhan dan pemulihan bagi pasien. Banyak kalangan masyarakat yang ingin berobat kerumah sakit baik orangtua maupun termasuk didalamnya anak usia dini. Berdasarkan hal tersebut peneliti tertarik suatu pencarian pola dari data yang berskala besar dan mengasosiasikan data yang satu dengan yang lainnua dengan menggunakan algoritma Apriori. Dengan demikian maka penyakit yang diderita anak usia dini dapat diklasifikasikan dengan berdasarkan data rekam medis tersebut, sehingga pola dari penyakit anak usia dini tersebut dapat diketahui. Informasi yang dihasilkan dapat digunakan oleh pihak Rumah Sakit maupun dokter yang bertugas di Rumah sakit tersebut untuk melakukan tindakan-tindakan yang diperlukan agar dapat mencegah penyebaran suatu peyakit dan juga dapat mengurangi resiko kematian pasien yang mengalaimi penyakit.
\end{abstract}

Kata Kunci: Algoritma Apriori, Data Mining,Pola Penyakit.

\begin{abstract}
Hospital is a place to treat patients with different types of diseases, and hospitals are also one of the health services that are medical, healing and recovery for patients. Many people who want to seek treatment at the hospital both parents and including early childhood. Based on this, researchers are interested in looking for patterns from large-scale data and associating data with one another using the Apriori algorithm. Thus, the diseases suffered by early childhood can be classified based on the medical record data, so that the pattern of early childhood disease can be known. The information produced can be used by the Hospital and the doctors on duty at the hospital to take the necessary actions in order to prevent the spread of a disease and also reduce the risk of death of patients suffering from disease.
\end{abstract}

Keywords: Apriori Algorithm, Data Mining, Pattern of Disease.

\section{PENDAHULUAN}

Rumah sakit merupakan tempat untuk menangani pasien dengan jenis penyakit yang berbeda-beda dan, Rumah Sakit juga merupakan salah satu pelayanan kesehatan yang bersifat pengobatan, penyembuhan dan pemulihan bagi pasien. Termasuk Rumah Sakit Umum Estomihi melaksanakan upaya kesehatan, mengutamakan penyembuhan dan pemulihan yang dilaksanakan secara serasi. Banyak kalangan masyarakat yang ingin berobat kerumah sakit baik itu orangtua maupun termasuk didalamnya anak usi dini.

Anak usia dini secara umum adalah anak-anak yang berusia di bawah 6 tahun, sehingga dari anak itu lahir hingga mencapai umur 6 tahun anak akan dikategorikan sebagai anak usia dini. Anak usia dini sering juga disebut dengan istilah golden age atau masa emas. Dimana pada masa ini hampir seluruh potensi anak mengalami masa peka untuk tumbuh dan berkembang secara cepat dan hebat. Pola penyakit yang sering terjadi pada anak usia dini yaitu penyakit syndrom nefrotik, penyakit ini merusak sistem penyaringan ginjal. Ketika albumin darah keluar, maka otomatis kadar protein dalam darah akan turun. Hal ini lah yang akan menimbulkan serangkaian gejala sindrom nefrotik, seperti cairan merembes keluar dari pembuluh darah terkecil (kapiler) tubuh dan mengendap ke dalam jaringan disekitarnya. Hal ini menyebabkan pembengkakan, mata sembab, kaki bengkak dan bisa bengkak seluruh tubuh. Pada kondisi normal, urine biasanya tidak mengandung protein, sindrom nefrotik juga mempunyai gejala sampingan seperti : mudah lelah, nafsu makan menurun, muntah dan diare, serta penyusutan otot dan perubahan warna kulit menjadi putih (leukonychia)[1].

Selain itu masyarakat pada umumnya, atau rumah sakit pada khususnya kurang mengetahui pola penyakit yang diderita oleh anak usia dini, sehingga penyakit syndrom nefrotik yang diderita oleh anak usia dini saat ini semakin bertambah. Untuk mengetahui pola data penyakit anak usia dini , diperlukan suatu cara untuk menganalisa pola dan penyebab yang mempengaruhi terjadinya suatu penyakit yaitu dengan memanfaatkan data mining.

Berdasarkan masalah yang diuraikan di atas maka penulis menggunakan Algoritma Apriori. Algoritma Apriori merupakan suatu metode untuk mencari pola hubungan antar satu atau lebih item dari dataset. Dengan demikian maka penyakit yang di derita anak usia dini dapat klasifikasikan berdasarkan data rekam medis tersebut, sehingga pola dari penyakit anak usia dini tersebut dapat diketahui. Dengan diketahui pola dari penyakit anak usia dini maka penyakit yang di derita oleh anak usia dini tersebut dapat ditangani dengan baik serta dapat mencegah atau mengurangi penyakit yang akan dialami pasien.Berdasarkan penelitian yang dilakukan penulis menyimpulkan bahwa metode algoritma apriori dapat melakukan penelusuran pada data historis untuk mengidentifikasi pola penyakit yang diderita pada anak usia dini, dan penelitian yang dilakukan oleh penulis dengan menemukan hubungan antar item penyakit anak usia dini untuk menemukan pola-pola hubungan yang berbeda[2].

Penggunaan aplikasi weka dalam pembuatan data mining dikarenakan aplikasi weka memiliki algoritma machine learning yang dapat digunakan untuk melakukan generalisasi atau formulasi dari sekumpulan data sampling. Kelebihan aplikasi weka terletak pada algoritma yang semakin lengkap dan canggih, tetapi keberhasilan data mining tetap terletak pada 
faktor pengetahuan manusia yang melakukan pengumpulan data yang berkualitas dan pengetahuan yang diperlukan untuk menjamin keakuratan formulasi yang diharapkan..

\section{METODE PENELITIAN}

\subsection{Data Mining}

Data mining, sering juga disebut knowledge discovery in database (KDD), adalah kegiatan yang meliputi pengumpulan, pemakaian data historis untuk menemukan keteraturan, pola atau hubungan dalam set data berukuran besar[1]. Keluaran dari data mining bisa dipakai untuk memperbaikin pengambilan keputusan dimasa depan Dari defenisi-defenisi yang telah disampaikan, hal penting yang terkait dengan data mining adalah:

1. Data mining merupakan suatu proses otomatis terhadap data yang sudahada.

2. Data yang akan diproses berupa data yang sangat besar.

3. Tujuan data mining adalah mendapatkan hubungan atau pola yang akan mungkin memberikan indikasi yangbermanfaat

\subsection{Algoritma Apriori}

Algoritma Apriori bertujuan untuk menemukan frequent itemset yang dijalankan pada sekumpulan data. Pada iterasi ke-k, akan ditemukan semua itemset yang memiliki k item, disebut dengan k-itemset. Berikut ini adalah dasar algoritma apriori[6]:

1. Membangun Analisa pola frekuensi tinggi

2. Pembentukan aturan assosiatif.

3. Analisa Penerapan Algoritma Apriori

Tahap ini mencari kombinasi item yang memenuhi syarat minimu dari nilai support dari data penyakit. Nilai support sebuah item diperoleh dengan rumus 1 berikut:

$$
\begin{aligned}
& \text { Support }(A)=\quad \frac{\text { Jumlah pasien yang mengandung } A}{\text { Jumlah pasien }} \\
& \text { Support }(A, B)=P(A \cap B)=\frac{\text { jumlah pasien yang mengandung A dan } B}{\text { Jumlah pasien }} .
\end{aligned}
$$

\subsection{Anak Usia Dini}

Masa anak usia dini sering disebut dengan istilah "golden age" atau masa emas. Pada masa ini hampir seluruh potensi anak mengalami masa peka untuk tumbuh dan berkembang secara cepat dan hebat. Perkembangan setara anak tidak sama karena setiap individu memiliki perkembangan yang berbeda. Makanan yang bergizi dan seimbang serta stimulasi yang intensif sangat dibutuhkan unuk pertumbuhan dan perkembangan tersebut. Apabila stimulasi secara intensif dari lingkungannya, maka anak akan mampu menjalani tugas perkembangannya dengan baik. Sedangkan hakikat anak usia dini adalah individu yang unik dimana ia memiliki pola pertumbuhan dan perkembangan dalam aspek fisik, kognitif, sosioemosional, kreativitas, bahasa dan komunikasi yang khusus yang sesuai dengan tahapan yang sedang dilalui oleh anak tersebut. Usia dini merupakan masa emas, masa ketika anak mengalami pertumbuhan dan perkembangan yang pesat. Pada usia ini anak paling peka dan potensial untuk mempelajari sesuatu, dan rasa ingin tau anak sangat besar [7].

\section{HASIL DAN PEMBAHASAN}

Rumah Sakit adalah tempat untuk menangani pasien dari berbagai daerah dan jenis penyakit tersebut berbeda-beda, karena cara hidup dan lingkungan berperan dalm perjalanan penyakit. Rumah sakit juga merupakan salah satu pelayanan kesehatan yang bersifat pengobatan, penyembuhan dan pemulihan bagi pasien. Termasuk Rumah Sakit Estomihi melaksanakan upaya kesehatan mengutamakan penyembuhan dan pemulihan yang dilaksanakan secara serasi. Banyak kalangan masyarakat yang ingin berobat kerumah sakit baik orang tua maupun termasuk didalamnya anak usia dini. Salah satu cara alternatif sebagai solusi dari masalah tersebut adalah membuat suatu pencarian pola atau hubungan Association rule (Aturan asosiatif) dari data yang berskala besar dan kaitannya erat dengan data mining yang dapat digunakan untuk menemukan aturan-aturan tertentu yang menasosiasikan data yang satu dengan data yang lainnya dengan Metode Algoritma Apriori bisa melakukan penelusuran pada data historis untuk mengidentifikasi pola data yang didasarkan pada sifat-sifat yang teridentifikasi sebelumnya..

Masalah yang di analisa berupa pencarian pola penyakit berdasarkan association rule dengan apriori. Data yang digunakan merupakan data penyakit yang diderita oleh Anak usia dini di Rumah Sakit Estomihi Medan dari . Pemrosesan data mining menggunakan algoritma apriori adalah meneukan hubungan antar item memerlukan pembacaan data penyakit yang besar untuk menemukan pola-pola hubungan yang berbeda. Berikut ini merupakan data rekam medis pasien di Rumah Sakit Estomihi Medan: 
Tabel 1. Data Rekam Medis Pasien RS Estomihi Medan

\begin{tabular}{clclc}
\hline No & Nama Anak & Jenis kelamin & Penyakit & Usia \\
\hline 1 & Roma & $\mathrm{Pr}$ & Infeksi Saluran Pernapasan Atas, Demam Dengue, Bacterial Infection & 5 \\
2 & Andi & $\mathrm{Lk}$ & Bacterial Infection, Infeksi Saluran Pernapasan Atas, Prolonged Fever & 5 \\
3 & Risma & $\mathrm{Pr}$ & Prolonged Fever, Viral Infection, Demam Dengue & 5 \\
4 & Didi & $\mathrm{Lk}$ & Demam Dengue, Infeksi Saluran Pernapasan Atas, Bacterial Infection & 5 \\
5 & Diana & $\mathrm{Pr}$ & Infeksi Saluran Pernapasan Atas, Bacterial Infection, Demam Dengue & 5 \\
6 & Dede & $\mathrm{Lk}$ & Demam Dengue, Infeksi Saluran Pernapasan Atas, Viral Infection & 5 \\
7 & Rudi & $\mathrm{Lk}$ & Infeksi Saluran Pernapasan Atas, Bacterial Infection, Prolonged Fever & 5 \\
8 & Ani & $\mathrm{Pr}$ & Infeksi Saluran Pernapasan Atas, Prolonged Fever, Viral Infection & 5 \\
9 & Afni & $\mathrm{Pr}$ & Infeksi Saluran Pernapasan Atas, Thypoid, Demam Dengue & 5 \\
10 & Rita & $\mathrm{Pr}$ & Infeksi Saluran Pernapasan Atas, Thypoid, Demam Rematik, & 5 \\
11 & Dedi & $\mathrm{Lk}$ & Thypoid, Demam Rematik, Infeksi Saluran Pernapasan Atas & 5 \\
12 & Eka & $\mathrm{Pr}$ & Viral Infection, Infeksi Saluran Pernapasan Atas, Demam Dengue & 5 \\
13 & Vera & $\mathrm{Pr}$ & Viral Infection, Bacterial Infection, Infeksi Saluran Pernapasan Atas & 5 \\
14 & Rado & $\mathrm{Lk}$ & Thypoid, Prolonged Fever, Bacterial Infection & 5 \\
15 & Santa & $\mathrm{Pr}$ & Bacterial Infection, Prolonged Fever, Infeksi Saluran Pernapasan Atas & 5 \\
16 & Dodi & $\mathrm{Lk}$ & Demam Rematik, Thypoid, Prolonged Fever & 5 \\
17 & Rama & $\mathrm{Pr}$ & Prolonged Fever, Demam Rematik, Infeksi Saluran Pernapasan Atas & 5 \\
\hline
\end{tabular}

Algoritma Apriori bertujuan untuk menemukan frequent itemset yang dijalankan pada sekumpulan data. Pada iterasi ke-k, akan ditemukan semua itemset yang memiliki k item, disebut dengan k-itemset. Berikut ini adalah dasar algoritma apriori:

1. Membangun Analisa pola frekuensi tinggi

2. Pembentukan aturan assosiatif.

3. Analisa Penerapan Algoritma Apriori

Untuk mengetahui pola penyakit yang terjadi di rumah sakit Estomihi Medan, maka diambil data anak usia dini dan penyakit yang terjadi dengan 7 kasus penyakit terbanyak yang diderita oleh pasien sebagai berikut:

\subsection{Analisa Pola Frekuensi Tinggi}

Tahap ini mencari kombinasi item yang memenuhi syarat minimu dari nilai support dari data penyakit. Nilai support sebuah item diperoleh dengan rumus 1 berikut:

Data tersebut diatas dalam database Anak dipresentasikan dalam bentuk seperti tampak pada Tabel 2. berikut

Tabel 2. Representasi Data Penyakit Anak

\begin{tabular}{|c|c|c|c|c|}
\hline \multicolumn{2}{|c|}{ Jln Anak } & \multicolumn{3}{|c|}{ Penyakit } \\
\hline & & \multicolumn{3}{|l|}{ Thypoid } \\
\hline & & \multicolumn{3}{|l|}{ Demam Dengue } \\
\hline & & \multicolumn{3}{|l|}{ Bacterial Infection } \\
\hline & & \multicolumn{3}{|l|}{ Prolenged Fever } \\
\hline & & \multicolumn{3}{|c|}{ Infeksi saluran pernapasan atas } \\
\hline & & \multicolumn{3}{|l|}{ Demam Rematik } \\
\hline & & \multicolumn{3}{|l|}{ Viral Infection } \\
\hline \multicolumn{5}{|c|}{ Tabel 3. Calon kandidat Pertama } \\
\hline Anak & & Penyakit & Support & Support (\%) \\
\hline 1 & & & 5 & 294,12 \\
\hline 2 & & m Dengue & 6 & 352,94 \\
\hline 3 & & rial Infection & 8 & 294,12 \\
\hline 4 & & iged Fever & 8 & 294,12 \\
\hline 5 & & i saluran pernapasan atas & 14 & 823,53 \\
\hline 6 & & m Rematik & 4 & 235,29 \\
\hline 7 & & Infection & 5 & 294,12 \\
\hline
\end{tabular}

Tabel 4. Calon 2-itemset

\begin{tabular}{lcc}
\hline \multicolumn{1}{c}{ Combinasi } & Support & Support (\%) \\
\hline Thypoid, Demam dengue & 1 & 176,47 \\
Thypoid, Bacterial Infection & 1 & 58,82 \\
Thypoid, Prolonged Fever & 2 & 117,65 \\
\hline
\end{tabular}




\begin{tabular}{llc}
\hline Thypoid, Infeksi Saluran Pernapasan & 3 & 176,47 \\
Thypoid, Viral Infection & 3 & 176,47 \\
Thypoid, Demam Rematik & 3 & 176,47 \\
Demam Dengue, Bacterial Infection & 3 & 176,47 \\
Demam Dengue, Prolonged Fever & 1 & 176,47 \\
Demam Dengue, infeksi Saluran Pernapasan Atas & 6 & 352,94 \\
Demam Dengue,Viral Infection & 3 & 176,47 \\
Demam Dengue, Demam Rematik & 0 & 0 \\
Bacterial Infection, Prolenged Fever & 4 & 235,29 \\
Bacterial Infection, Infeksi Saluran Pernapasan Atas & 7 & 411,76 \\
Bacterial Infection, Viral Infection & 2 & 117,65 \\
Bacterial Infection, Demam Rematik & 0 & 0 \\
Prolonged Fever, Infeksi Saluran Pernapasan & 7 & 411,76 \\
Prolonged Fever, Viral Infection & 3 & 176,47 \\
\hline
\end{tabular}

Tabel 5. berikut yang menunjukkan calon 2-itemset dari data penyakit pada Tabel 4.1 dari data tersebut diatas, jika ditetapkan nilai $\phi=3$ maka F2 \{Demam Dengue, Bacterial Infection\}, \{Demam Dengue, Infeksi Saluran Pernapasan Atas\}, BBacterial Infection\}, \{Prolonged Fever,Infeksi Saluran Pernapasan\}.

Tabel 5. Calon 3-Itemset

\begin{tabular}{lc}
\hline \multicolumn{1}{c}{ Combination } & Count \\
\hline Demam Dengue, Bacterial Infection, Saluran Pernapasan Atas & 3 \\
Demam Dengue, Infeksi Saluran Pernapasan Atas, Viral Infection & 1 \\
\hline
\end{tabular}

Dengan demikian F3 $=\{$ Demam Dengue, Bacterial Infection, Infeksi Saluran Pernapasan Atas $\}\}$, karena hamya kombinasi inilah yang memilliki frekuensi kemunculan $>=\Phi$

\subsection{Pembentukan Aturan Assosiatif}

Setelah semua pola frekuensi tinggi ditentukan, barulah dicari aturan assosiatif yang memenuhu syarat minimum untuk confidence dengan menghitung confidence aturan assosiatif A dan B nilai confidence dari aturan A dan B diperoleh dari Rumus 3 berikut :

Confidence $=\mathrm{P}(\mathrm{B} \mid \mathrm{A})=\frac{\text { Jumlah pasien yang mengandung A dan } \mathrm{B}}{\text { Jumlah pasien yang mengandung } \mathrm{A}}$

Dari F3 yang telah ditemukan, dapat dilihat besarnya nilai support dan confidence dari calon aturan asosiasi seperti tampak pada tabel 6. berikut:

Tabel 6. Calon Aturan Asosiasi Dari F3

\begin{tabular}{lll}
\hline If Antecedent then Confidence & Support & Confidence \\
\hline IF Mengidam Demam Dengue end Bacterial Infection Then Infeksi Saluran & $3 / 17=27,3 \%$ & $3 / 4=75 \%$ \\
Pernapasan Atas & & \\
If Mengidam Demam Dengue end Saluran Pernapasan Atas Then Viral Infection & $3 / 17=27,3 \%$ & $3 / 6=50 \%$ \\
\hline
\end{tabular}

Confidence minimal adalah 75\% maka aturan yang bisa terbentuk adalah aturan dengan 1 antecedent berikut: "IF Mengidam Demam Dengue end Bacterial Infection, Then Mengidam Infeksi Saluran Pernapasan Atas" Sementara itu calon aturan asosiasi dari F2 dilihat dari pada tabel 7. berikut:

Tabel 7. Calon Aturan Asosiasi Dari F2

\begin{tabular}{lll}
\hline IF Antecedent then Consequent & Support & Confidence \\
\hline IF Mendidam Demam Dengue Then Mengidam Bacterial Infection & $3 / 17=17,6 \%$ & $3 / 7=41,8 \%$ \\
IF Mengidam Bacterial Infection Then Mengidam Demam Dengue & $3 / 17=17,6 \%$ & $3 / 8=37,5 \%$ \\
IF Mengidam Demam Dengue, Then Mengidam Infeksi Saluran Pernapasan Atas & $5 / 17=29,4 \%$ & $6 / 7=85,7 \%$ \\
IF Mengidam Infeksi Saluran Pernapasan Atas Then Mengidam Demam Dengue & $5 / 17=29,4 \%$ & $5 / 13=38,4 \%$ \\
IF Mengidam Bacterial Infection Then Mengidam Infeksi Saluran Pernapasan Atas & $6 / 17=35,2 \%$ & $6 / 8=75 \%$ \\
IF Mengidam Infeksi Saluran Pernapasan Atas Then Mengidam Bacterial Infection & $6 / 17=35,2 \%$ & $6 / 13=46,1 \%$ \\
IF Mengidam Prolonged Fever Then Mengidam Infekai Saluran Pernapasan Atas & $5 / 17=29,4 \%$ & $5 / 8=62,5 \%$ \\
IF Mengidam Infeksi Saluran Pernapasan Atas Then Mengidam Prolonged Fever & $5 / 17=29,4 \%$ & $5 / 13=38,4 \%$ \\
\hline
\end{tabular}

Aturan assosiasi final terurut berdasarkan Support Confidence terbesar dapat dilihat pada tabel 8. berikut: 
Tabel 8. Aturan Assosiasi Final

\begin{tabular}{llll}
\hline IF Antecedent then Consequent & Support & Confidence & $\begin{array}{l}\text { Support x } \\
\text { Confidence }\end{array}$ \\
\hline IF Mendidam Demam Dengue Then Mengidam Bacterial Infection & $4 / 17=36,4 \%$ & $4 / 7=41,8 \%$ & 0,1818 \\
IF Mengidam Bacterial Infection Then Mengidam Demam Dengue & $4 / 17=36,4 \%$ & $4 / 8=37,5 \%$ & 0,2424 \\
IF Mengidam Demam Dengue, Then Mengidam Infeksi Saluran & $6 / 17=54,5 \%$ & $6 / 7=85,7 \%$ & 0,4091 \\
$\begin{array}{l}\text { Pernapasan Atas } \\
\text { IF Mengidam Infeksi Saluran Pernapasan Atas Then Mengidam }\end{array}$ & $6 / 17=54,55$ & $5 / 13=38,4 \%$ & 0,3636 \\
$\begin{array}{l}\text { Demam Dengue } \\
\text { IF Mengidam Bacterial Infection Then Mengidam Infeksi Saluran }\end{array}$ & $5 / 17=45,5 \%$ & $6 / 8=75 \%$ & 0,3788 \\
$\begin{array}{l}\text { Pernapasan Atas } \\
\text { IF Mengidam Infeksi Saluran Pernapasan Atas Then Mengidam }\end{array}$ & $5 / 17=45,5 \%$ & $6 / 13=46,1 \%$ & 0,2525 \\
$\begin{array}{l}\text { Bacterial Infection } \\
\text { IF Mengidam Prolonged Fever Then Mengidam Infekai Saluran }\end{array}$ & $3 / 17=27,3 \%$ & $5 / 8=62,5 \%$ & 0,2045 \\
$\begin{array}{l}\text { Pernapasan Atas } \\
\text { IF Mengidam Infeksi Saluran Pernapasan Atas Then Mengidam }\end{array}$ & $3 / 17=27,3 \%$ & $5 / 13=38,4 \%$ & 0,0909 \\
Prolonged Fever & & & \\
\hline
\end{tabular}

Berikut Tabel penerapan cara kerja Apriori:

Tabel 9. Data Pasien

\begin{tabular}{cl}
\hline Code Pasien & \multicolumn{1}{c}{ Item Penyakit } \\
\hline 1 & Infeksi Saluran Pernapasan Atas,Demam Dengue, Bacterial Infection \\
2 & Bacterial Infection, Infeksi Saluran Pernapasan Atas, Prolonged Fever \\
3 & Prolonged Fever, Viral Infection, Demam Dengue \\
4 & Demam Dengue, Infeksi Saluran Pernapasan Atas, Bacterial Infection \\
5 & Infeksi Saluran Pernapasan Atas, Bacterial Infection, Demam Dengue \\
6 & Demam Dengue, Infeksi Saluran Pernapasan Atas, Viral Infection \\
7 & Infeksi Saluran Pernapasan Atas, Bacterial Infection, Prolonged Fever \\
8 & Infeksi Saluran Pernapasan Atas, Prolonged Fever, Viral Infection \\
9 & Bacterial Infection, Demam Dengue, Demam Rematik \\
10 & Infeksi Saluran Pernapasan Atas, Thypoid, Demam Dengue, \\
11 & Thypoid, Demam Dengue, Infeksi Saluran Pernapasan Atas \\
\hline
\end{tabular}

1. Pada iterasi pertama Algoritma, setiap item adalah anggota sari set calon 1-itemset, C1. Agoritma akan secara langsung memriksa semua penyait yang ada untuk dapat menghitung kejadian munculnya setiap item. Jika diasumsikan bahwa minimum support yang dibutukan adalah 2 (misalnya min_sup $=4 / 17=36,4 \%$. Set dari 1 -itemset, L1, dapat ditentukan yaitu semua calon 1-itemset yang memenuhi minimum support.

Tabel 10. C1 dan L1 Untuk mencari 1-itemset

\begin{tabular}{cl}
\hline Jumlah Anak & Item Penyakit \\
\hline 2 & Thypoid \\
8 & Demam Dengue \\
6 & Bacterial Infection \\
4 & Prolonged Fever \\
9 & Infeks Saluran Pernapasan Atas \\
3 & Viral Infection \\
1 & Demam Rematik \\
\hline
\end{tabular}

Untuk menemukan 2-itemset, L2, algoritma ini menggunakan pengkombinasian C1 dengan L1 untuk menhasilkan candidate set dari 2-itemset, C2 . C2 merupakan hasil kombinasi dai L1. Penyakit yang ada dalam database D diperiksa dan support count dari setiap calon itemset yang ada di C2 ditambahkan, seperti yang diajukan pada Tabel

Tabel 11. C2 dan L2, Untuk mencari 2-itemset

\begin{tabular}{lc}
\hline Combinasi & Count \\
\hline Thypoid, Demama Dengue & 2 \\
Thypoid, Bacterial Infection & 0 \\
Thypoid, Prolonged Fever & 0 \\
Thypoid, Infeksi Saluran Pernapasan Atas & 2 \\
Thypoid, Viral Infection & 0 \\
Thypoid, Demam Rematik & 0
\end{tabular}


Demam Dengue, Bacterial Infection 4

Demam Dengue, Prolonged Fever

Demam Dengue, Infeksi Saluran Pernapasan Atas 6

Demam Dengue, Viral Infection 2

Demam Dengue, Demam Rematik 1

Bacterial Infectioan, Prolonged Fever 2

Bacterial Infectioan, Infeksi Saluran Pernapasan Atas 5

Bacterial Infectioan, Viral Infection 0

Bacterial Infectioan, Demam Rematik $\quad 1$

Prolonged Fever, Infeksi Saluran Pernapasan Atas $\quad 3$

Prolonged Fever, Viral Infection 2

Prolonged Fever, Demam Rematik 0

Infeksi Saluran Pernapasan Atas, Viral Infection 2

Infeksi Saluran Pernapasan Atas, Demam Rematik $\quad 0$

Viral Infection, Demam Rematik 0

2. Set dari 2-itemset, L2 dapat ditentukan, yaitu semua candidate 2 itemset yang memenuhi minimum support. Proses untuk menghasilkan suatu set candidate dari 3-itemset, C2, dijelaskan secara lebih detail pada Tabel4.7, 4.8, 4.9 pertama dapatkan C3, yaitu dengan cara mengkombinasikan L2 dengan C2, maka menghasilkan ( Demam Dengue, Bacterial Infection, infeksi Saluran Pernapasan) berdasarkan pada algoritma apriori, maka semua sumset dari frequent itemset diatas, harus juga frequent, dapat dipastikan kemudian ke-empat candidat terakhir tidak mungkin akan frequent. Oleh karena itu harus disingkirkan dari C3, dengan demikian dapat menghemat usaha yang tidak diperlukan untuk melakukan perhitungan Algoritma akan melakukan kombinasi antara C3 dengan L3 untuk menghasilkan candidate dari 4-itemset, C4. Dengan demikian, C4?, dan algoritma berhenti karena telah menemukan frequent itemset.

Tabel 12. Tabel prediksi pola yang sering diderita anak usia dini

\begin{tabular}{lc}
\hline Combination & Support \\
\hline Demam Dengue, Infeksi Saluran Pernapasan Atas & $85,7 \%$ \\
Bacterial Infection, Infeksi Saluran Pernapasan Atas, & $75 \%$ \\
\hline
\end{tabular}

Jadi pola data yang sering diderita anak usia dini yaitu \{Demam Dengue, Infeksi Saluran Pernapasan Atas\}, Dan \{Bacterial Infection, Infeksi Saluran Pernapasan Atas\} Dilihat Dari Tabel 12.

\section{KESIMPULAN}

Berdasarkan hasil-hasil analisis dan percobaan yang dilakukan pada bab sebelumnya, maka kesimpulan yang dapat diambil adalah sebagai berikut:

1. Pola penyakit pasien anak usia dini dapat diketahui dengan menggunakan data rekam medis dari rumah sakit dan mengambil data-data yang dapat mempengaruhi penyakit pasien tersebut.

2. Penerapan Algoritma Apriori pada teknik data mining sangat efisien dan dapat mempercepat proses pembentukan pola kombinasi itemset pada anak usia dini pada RS Estomihi , yaitu dengan support dan confidence yang tertinggi..

3. Penghitungn data mining dengan weka sangat mudah dilakukan dengan mengi-input data ke dalam sebuah file yang berformat .csv kemudian menyimpan file tersebut dengan format .arrf yang terdapat di dalam weka untuk mendapatkan hasil prediksi dari aplikasi tersebut.

\section{REFERENCES}

[1] Usman, Nurdin;, "Implementasi," konteks informasi berbasis kurikulum, no. Grasindo, p. 72, 2002.

[2] M.sc, Dr. Suyanto, S.T.,;, DATA MINING untuk klasifikasi dan klasterisasi data, Jawa Timur: INFORMATIKA, 2017.

[3] Sutrisno; Afriyudi; Widianto;, "PENERAPAN DATA MINING PADA PENJUALAN MENGGUNAKAN METODE CLUSTERING," Jurnal Ilmiah Teknik Informatika Ilmu Komputer, vol. X, p. 4, 2010.

[4] Hermawati , Fajar Astuti;, DATA MINING, Yogyakarta: ANDI, 2013.

[5] Luthfi Emha Taufiq dan kusrini, ALGORITMA DATA MINING, Yokyakarta: ANDI, 2009.

[6] C. N. Parkinson, M. Rustomji and W. E. Viera, Marketing Potensial, semarang: Dahara Prize Semarang, 1993.

[7] Rony Setiawan, "PENERAPAN DATA MINING MENGGUNAKAN ALGORITMA K-MEANS CLUSTERING UNTUK MENENTUKAN STRATEGI PROMOSI MAHASISWA BARU," JURNAL LENTERA ICT, vol. 3, p. 80, 2016.

[8] T. Yulianita and I. Deden , "implementasi algoritma K-Modes untuk menentukan prioritas rehabilitasi daerah aliran sungai berdasarkan parameter lahan kritis," URECOL, no. universitass muhammadiyah magelang, p. 434, 2017. 